\title{
Evolution of Free Economic Zones: A Functional Taxonomy
}

\author{
Edward E. Marandu \\ University of Botswana, Faculty of Business \\ Marketing Department \\ Paul T. Mburu \\ University of Botswana, Faculty of Business \\ Marketing Department \\ Donatus Amanze \\ University of Botswana, Faculty of Business \\ Marketing Department
}

\begin{abstract}
This study investigates the evolution of Free Economic Zones (FEZs) using the functional criteria. The methodology of the study involved analysis of the literature. The study makes five main revelations. First, the evolution of FEZ is in general consistent with theory of city life-cycle that states that a city will undergo different stages such as birth, growth, flourishing and decline. And at each stage there are several specific challenges concerning its industrial structure, enterprise structure, spatial structure and so on. Second, the study identifies five evolutionary phases of FEZs which are: Free Trade Zones, Export Processing Zones, Science Industrial Parks, Service Economic Zones and Special Economic Zones; each of these basic zones contain several variants. Third, as the typical FEZs evolve they change the focus of their functions both vertically and horizontally. In vertical terms the zones change the focus of their activities from trade related to manufacturing of the traded goods. In horizontal terms the zones expand their scope by embracing more sectors such as services, science and residential issues. Fourth, there is a progressively stronger orientation toward technology and skill intensive manufacturing and services. Fifth, FEZs are attractive to investors because of the existence of policy failures in the greater host economy: as policy reforms happen investors will see no need for staying in the FEZs and the relative significance of FEZs in economic terms can be expected to decline; at this point FEZ and non-FEZ firms would be treated equally. These findings lead to two general guidelines for sustainable zone development in a developing country context. First, policy makers should start by encouraging trade-intensive FEZ activities in the zones, followed by labor-intensive manufacturing; later on upgrade to technology- and skill-intensive manufacturing and services. Second, policy makers should encourage FDI in industries in which the country has comparative advantage; this increases the likelihood that development will be sustained long after FEZ incentives are removed and all firms are being treated equally in an economy.
\end{abstract}

Key words: Free Economic Zones (FEZ); Foreign Trade Zones (FTZ); Evolution; Economic Zones; Export Processing Zones (EPZs); Economic and Technological Development Zones (ETDZs).

\section{INTRODUCTION}

The objective of this paper is to explore the evolution of Free Economic Zones (FEZs) from Free Economic Zones to Special Economic Zones. The criterion used to gauge the evolution from one phase to another is the functions undertaken within a zone. This study is motivated by confusion in the extant literature created by the numerous terminologies and definitions around the concept; there is a need to sort out the nomenclature. The paper is based on the observation that most studies (Warr, 1987; Wong and Chu, 1984; Jenkins, Esquivel, \& Felipe, 
1998; Centre for Education and Documentation, 2009) on the subject focus on the static economic analysis of benefits and costs of FEZs, but little attention has been given to their evolution. In most studies the type of FEZ adopted is invariably taken as given. Little attention is given to "why, when and how" FEZs evolve or adapt to changes in the environment. Failure to take into account the evolutionary nature of FEZ has led to numerous terminologies for FEZ, depending on what stage in the evolutionary process an analyst is looking at. The approach taken in this study is dynamic in the sense that a time element is somewhat incorporated into the FEZ model. The analysis is based on previous studies and secondary sources and a developing country context is assumed.

In the light of the above broad objective and observation, the issues to be studied revolve around seeking answers to two critical questions:

1. How can FEZs be classified into various types or generations on the basis of the functions performed?

2. What theoretical framework can be used to explain and predict the evolution of FEZ?

\section{The Concept of FEZs}

\section{BACKGROUND: THE CONCEPT, HISTORY AND FEATURES}

Perhaps a logical starting point for studying the evolution of special economic zones is to begin by sorting out the nomenclature on the subject. Free Economic Zone is a generic term used to refer to various types of areas within a nation that offer incentives to attract foreign and local direct investment. The generic free zone concept has evolved over time resulting in a variety of zones with differing objectives and functions. Table 1 gives an overview of the main features of a Zone that help us to understand the evolutionary nature of FEZs. The first three rows show that on the basis of the functions performed, modern FEZs can be classified into five basic types and each basic zone in turn consists of several variants or simply synonyms. The five basic zones are Free Trade Zones (12 variants), Export Processing Zones (14 variants), Science Economic Zones (14 variants), Service Economic Zones (8 variants), and Special Economic Zones (3 variants); a total of 51 variants.

The existence of a myriad of terminologies has resulted in confusion in such a way that different terms are used to describe very similar, often identical, phenomena. In some countries the term SEZ is used as a generic term instead of FEZ (Farole \& Akinci, 2011). In this study Free Economic Zone (FEZ) will be used as the generic term that refers to various types of areas within a nation that offer incentives to attract foreign and local direct investment; the term Special Economic Zone (SEZ) will be reserved for the comprehensive zones like the Chinese Shenzhen.

The term FEZ is preferred in this study as a general designation to cover all types of zones, because it can generalize the dominant characteristics of them. "Free" refers to the relaxation of economic laws and immigration policies applicable nationwide so as to benefit firms established within the area chosen as an FEZ. "Economic" refers to the type of activities permitted within the zone. Zone refers to the geographic space demarcated as an FEZ (Farole, 2011: 26-27). FEZ authorities act as 'governments' and ruling authorities within the designated zones. Zone companies are treated as operating from outside the country and their goods treated as imports.

It is observed that many of the terminologies used include the word "free": for example, "Duty free", "free port", "tax free zone", "export free zone" and "free tourist zone" - all these are indistinguishable from each other in terms of meaning. Even though it may seem to be mainly a 
matter of semantics, it is useful however, to distinguish between the five basic groups (rather than the variants) since they imply differences in approaches to promoting them. We therefore adopt with adaptation the following definition (Ge, 1999, p. 1268) which is rather broad:

"A free economic zone is, in general terms, a geographic area within the territory of a country where economic activities of certain kinds are promoted by a set of policy instruments that are not generally applicable to the rest of the country".

\section{History of FEZs}

FEZs have a long history dating from ancient times. However, before the 1960s, these FEZs only played a minor role in the world economy. The World Bank estimated that in 2008 there were 3000 zones in 135 countries, accounting for over 68 million direct jobs and over $\$ 500$ billion of direct trade related value added within zones (World Bank, 2008). FEZs are found in both developing and developed countries.

\section{Objectives and Features of FEZs}

The main objectives of FEZs are: to attract domestic and foreign direct investment, creation of employment opportunities and to earn foreign exchange (Rondinelli, 1987). To achieve these goals several incentives are normally offered to investors, however, a few features or incentives for firms are typical: development of infrastructure facilities, greatly reduced customs rates, reduction of red tape, tax breaks, relaxed legislation, absence of labour union activity, subsidised land and bureaucracy less susceptible to corruption.

\section{FIVE GENERATIONS OF FREE ECONOMIC ZONES}

Trade is the cornerstone of any form of FEZ. The lowest level of FEZ usually involves trade only; higher forms of zones go beyond simple trading to include manufacturing, services and finally the modern all-in-one zones that combine all these operations and residential issues. Table 1 gives an overview of the five broad zone types and four different dimensions or characteristics of FEZs employed in this study to help us understand their evolutionary nature. The dimensions used are the functions, nomenclature, variants, examples of zones, time frame and stage of evolution. We now turn to the discussion of each zone type and its historical evolution that has led to the modern FEZs. It should be helpful in enabling the reader to understand and reflect on the functional variations of contemporary zones.

\section{Free Trade Zones (FTZ): First Generation}

In a Free Trade Zone (FTZ), as the name implies, trade is the focus of the zone. It is the oldest and most common form of FEZ. It is a geographic area where goods may be imported in and undergo trade related processes (such as warehousing, storage, sales, exhibition) and light processing operations (such as packaging, labeling, quality control, sorting) and re-exported without the intervention of the national customs authorities. Only when the goods are sold within the host country do they become subject to the prevailing customs duties. Free-trade zones are normally established around major seaports, international airports and national borders, which are areas with many geographic advantages for trade.

FTZs have grown substantially in number and size in recent years, but the concept is not a new one. The concept can be traced as far back as in the ancient times when man started engaging in external trade. During this period enterprising nations started importing goods from one country with the purpose of re-exporting to another. This entrepot trade created the need for secure areas at ports or in strategic locations along trade routes where goods can be stored before re-export. These areas became free zones when government allowed the goods to move in the zone free of local prohibitions, taxation, duties, and excises. 
In ancient times, FTZ-like conditions existed in the Phoenician city of Tyre at around 300 BC (Farole, 2011) and at the Greek Island of Delos which as a result became one of the wealthiest islands in the world for nearly a century (Haywood, 2000). During the colonialist days from the early eighteenth to the late nineteenth century, the English and the French developed the following FTZs: Gibraltar in 1704, Singapore in 1819 (FIAS, 2008), Hong Kong in 1841, Aden in 1853 and Djibouti in 1859 (Zhan, 1993). The vast majority of early zones were closely associated and generally collocated with ports. By 1900, 11 FTZs existed globally; of these, 7 were in Europe and 4 in Asia (Farole, 2011: 32). Other examples of FTZs include Dubai (United Arab Emirates), Colón (Panama), Copenhagen, Stockholm and Gdańsk (Poland).

FTZ can be specialized or of general purpose. For example, there are more than 20 Free Trade Zones operating in Dubai and each is designed around one or more specialized industry categories, and licenses are offered only to companies falling within those categories. These industry groups include Auto, Internet, Gold \& Diamond and Commodities.

Essentially FTZs function as trading and reshipping zones with limited light processing operations, if any. However, the revolutionary decline in the transportation costs made it possible to move goods efficiently towards where processing or manufacturing had comparative advantages. Thus the "Free Trade Zones" evolved in to Export Processing Zones (EPZs).

\section{Export Processing Zone (EPZ): Second Generation}

EPZ is an extension of FTZ into manufacturing. An EPZ is similar to FTZ but is set up for the purpose of managing export manufacturing. It is an area where one is allowed to import plant, machinery, equipment and material for export manufacturing, without payment of customs duties. The imported goods are subject to customs or duty payment if used for home consumption. Other benefits of operating such enterprises include; streamlined Government red tape allowing for one stop registration and licensing and tax concessions. EPZs are economic enclave within which manufacturing for export occurs under virtual free trade conditions. The zones are often used by transnational corporations to set up factories to produce labour intensive goods mainly for export or import substitution.

A "Single Unit EPZ" is a variation of the EPZ in which individual enterprises are provided with an EPZ status and allowed to locate anywhere in the national territory. This approach applies to existing enterprises that wish to have the benefits of the EPZ system but whose relocation costs would be too high or to new enterprises that have a compelling reason not to locate in an existing EPZ. Some countries have no EPZs per se, and the EPZ status is given to individual enterprises. In Mexico, the maquiladora status is of this type. Mauritius, one of Africa's most famous and successful examples of EPZ, is another example.

Manufacturing entered the realm of free economic zone activities only in the 20th century when free trade zones started being used for manufacturing also. Perhaps the world's first modern EPZ was established in Shannon, Ireland in 1958 (Farole, 2011). It was the result of an external threat. As aircraft technology developed, trans-Atlantic flights no longer needed to stop at the Shannon airport to refuel. To safeguard continued vitality of the airport as well as the town, Ireland reduced tariffs and lowered taxes in Shannon. It was a big success and is still in operation today. Shannon provided the basic model for EPZs, which was replicated across the globe in subsequent decades (Madani, 1999). 


\section{Table 1: The Evolution of Free Economic Zones: A Functional Typology}

\begin{tabular}{|c|c|c|c|c|c|c|}
\hline \multicolumn{2}{|c|}{ Functions $\rightarrow$} & \multirow{2}{*}{$\begin{array}{l}\text { Trade-based } \\
\text { Free Trade Zone }\end{array}$} & \multirow{2}{*}{$\begin{array}{l}\begin{array}{l}\text { Manufacturing- } \\
\text { based }\end{array} \\
\text { Export Processing } \\
\text { Zone }\end{array}$} & \multirow{2}{*}{$\begin{array}{l}\text { Science-based } \\
\begin{array}{l}\text { Science Industrial } \\
\text { Park }\end{array}\end{array}$} & \multirow{2}{*}{$\begin{array}{l}\begin{array}{l}\text { Services- } \\
\text { based }\end{array} \\
\text { Service } \\
\text { Economic } \\
\text { Zone } \\
\end{array}$} & \multirow{2}{*}{$\begin{array}{l}\text { Comprehesive } \\
\text { Special Economic } \\
\text { Zone }\end{array}$} \\
\hline \multirow{4}{*}{ 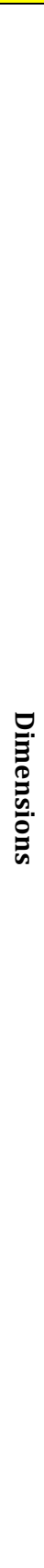 } & $\begin{array}{l}\text { Generic } \\
\text { Name } \\
\rightarrow \\
\end{array}$ & & & & & \\
\hline & 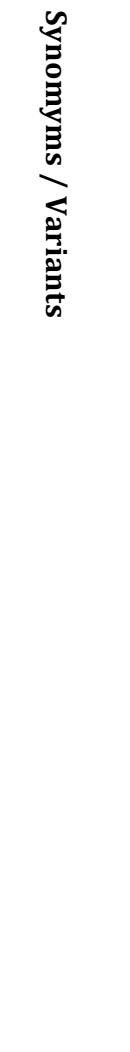 & 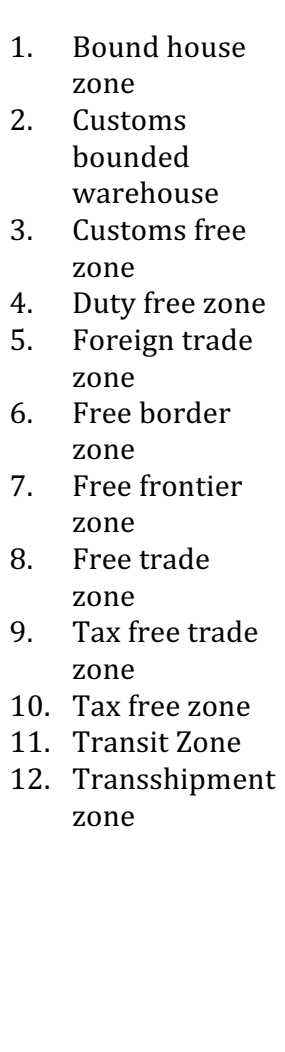 & 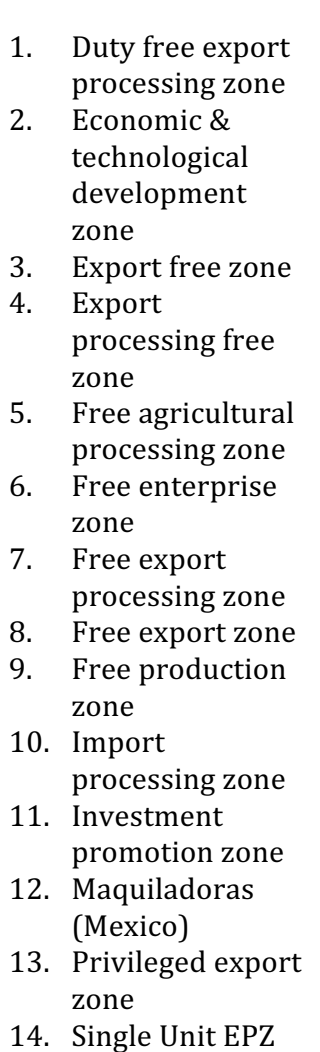 & 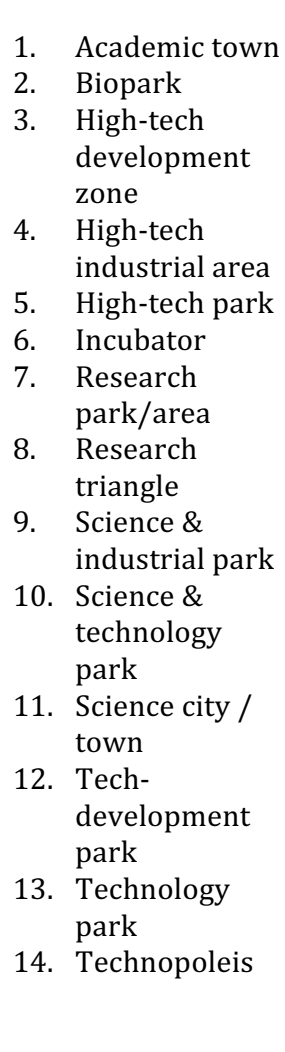 & 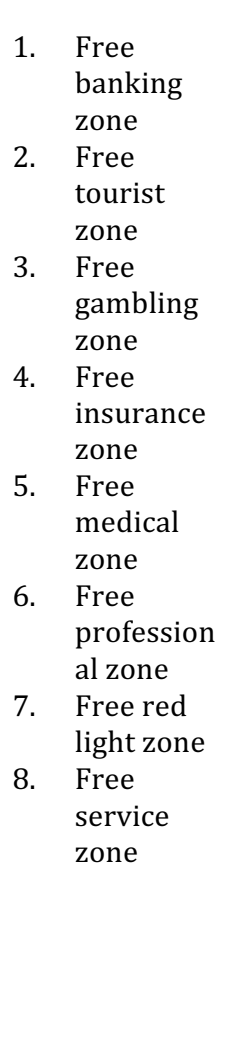 & $\begin{array}{l}\text { 1. Comprehensive } \\
\text { free port } \\
\text { 2. Comprehensive } \\
\text { free trade zone } \\
\text { 3. Freeport }\end{array}$ \\
\hline & 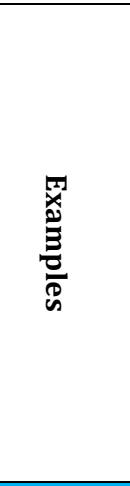 & $\begin{array}{l}\text { - Aden } \\
\text { - Colón - Panama } \\
\text { - Copenhagen } \\
\text { - Djibouti } \\
\text { - Dubai - U A } \\
\text { Emirates } \\
\text { - Genoa - Italy } \\
\text { - Gibraltar - } \\
\text { - Hamburg - } \\
\text { Germany } \\
\text { - Hong Kong } \\
\text { - Singapore } \\
\text { - Stockholm } \\
\end{array}$ & $\begin{array}{l}\text { - Shannon - Ireland } \\
\text { - Barranquilla - } \\
\text { Colombia } \\
\text { - Bataan - Philippines } \\
\text { - Kandla - India } \\
\text { - Kaoshiung - Taiwan } \\
\text { - Masan - South Korea } \\
\text { - Penang Island - } \\
\text { Malaysia }\end{array}$ & $\begin{array}{l}\text { - Silicon Valley - } \\
\text { California } \\
\text { - Hsinchu - Taiwan } \\
\text { - Austin Incubator - } \\
\text { Texas } \\
\text { - Tzukuba City - } \\
\text { Tokyo }\end{array}$ & & $\begin{array}{l}\text { - Aqaba - Jordan } \\
\text { - Brest - Belarus } \\
\text { - Tianjin - China } \\
\text { - Nakhodia - Russia } \\
\text { - Shenzhen - China } \\
\text { - Vyborg - Russia }\end{array}$ \\
\hline & Stage & First Generation & Second Generation & Third Generation & $\begin{array}{l}\text { Fourth } \\
\text { Generation } \\
\end{array}$ & Fifth Generation \\
\hline
\end{tabular}

Most early EPZs were established to promote industrialization, primarily through importsubstitution (Farole, 2011). However, EPZs have demonstrated ability to evolve because they can adapt functionally to changes in the local, national and international environment. For example, Taiwan and South Korea shifted from import-substituting industrialization in the 1950s to export-oriented industrialization in the 1960s. Import substitution was intended to foster local infant industries by reducing imports, but it could not overcome the lack of financial resources to import intermediate products. Therefore the EPZs were functionally reoriented to meet the need for export promotion (Chen, 1994) by accelerating labor-intensive manufacturing through exploiting their comparative advantage of cheap labour. The shift from import substitution to export oriented industrialization has been followed by a more recent 
trend towards science-based zones and service-based zones. These signalled what we may call third and fourth generation of FEZs, respectively.

\section{Science Based Zone: Third Generation}

The science-based zone aims at industrial upgrading by promoting high-tech industries. A science-based zone is an area managed in a manner to promote cutting edge state of the art scientific and technological innovation. It is a physical place supported by university-industrygovernment collaboration with the intent of creating high technology economic development to help move a country, region or industry or community from a basis of low-cost labour to one of technology. Its main products are computers, related hardware, software and other products.

Incentives such as tax holidays, reduced corporate taxes, duty-free importation of equipment and raw materials and government grants are often provided as part of the entire package to attract foreign and domestic companies to the area. Training programs in the zone produce bodies of specialists in such areas as semiconductors and Optoelectronics that few companies can afford alone. Specialists may share their expertise among themselves, and can apply their skills to problems of more than one company at a time. In addition the parks offer a number of other shared resources, such as reception, management, security, incubators, telecommunication hubs, restaurants, banks offices, convention center, parking, internal transportation, entertainment, sports facilities and so on. In this way, the zone offers considerable advantages to hosted companies.

Science zones provide a good example of how FEZ has evolved in adapting to economic changes in China. As labour costs in the Special Economic Zones rose, the investment environment became overcrowded and the original zones lost some of their appeal to investors (Chen \& de'Medic, 2009). This economic pressure, led to the establishment of Economic and Technological Development Zones (ETDZs). These zones are functionally specialized in developing capital- and technology-intensive industries. The zones help the country avoid overdependence on labour-intensive industrialization.

\section{Service Zones: Fourth Generation}

In recent years FEZs have expanded to include services. Each Zone can be established as a specialized or for general purpose services. The well-known examples of service zones are tourist and recreational zones, healthcare, academic services, financial services, gambling zones and so on (Pakdeenurit, Suthikarnnarunai, \& Rattanawong, 2014). A good example of service based zone is the creation of the Dubai International Financial Centre (DIFC) in 2004 which in just over 10 years has become one of the leading financial centres in the world.

\section{Special Economic Zones (SEZs): Fifth Generation}

Since the 1980s, the FEZ concept has evolved further from zones that deal with manufacturing or service or science into the more comprehensive special economic zones (SEZs). A Special Economic Zones is a large-scale FEZ that combines all types of activities trade, manufacturing, service, science and permits on-site residence; it provides a broad set of incentives and benefits that make all these happen. These SEZs are the largest type of all, as they encompass very large portions of a territory, include urban and rural areas, and incorporate large transport facilities such as ports and airports. SEZs can include entire economic regions, the populations that live and work in these regions, and all the economic activities that take place there. 
Using this description, Chinese SEZs (including the famous Shenzhen) would fall into this category, as does the Aqaba Special Economic Zone in Jordan (Jayanthakumaran, 2003). It is a recent form of economic zone, originating in China and gaining in popularity. China initiated its open-door policy and economic reforms by introducing Special Economic Zones in 1978. No other SEZ program has had as much impact, nationally and internationally, as the Chinese program. The first zones were established as a test of the controlled restructuring of the entire economy through the introduction of capitalism and foreign investment, after about 30 years of economic and political isolation since 1949. The strategy proved to be successful. China became the world's largest exporter of manufactured goods and the leading recipient of foreign direct investment among emerging economies.

\section{TOWARDS A THEORY OF FEZ - THE LIFE CYCLE}

It is important to find an existing or develop a new theory that can provide systematic explanation and prediction of evolution of FEZs. The notion of generality or broad application is important for helping policy-makers design strategies that are appropriate at a particular stage and in anticipation of the next stage of evolution. An examination of the pertinent literature reveals that the city life-cycle theory can be used as a base to discern the main concepts for explaining and predicting the evolution of FEZs. The theory of city life-cycle (Suazer-villa, 1985) says that a city undergoes different stages that include birth, growth, flourishing and decline (Figure 1). At each stage, there are several specific challenges concerning its industrial structure, enterprise structure and spatial structure.

\section{The FEZ Life Cycle}

Typical FEZs start (birth) as FTZs by attracting foreign traders who import goods that undergo trade related processes (such as warehousing, storage, sales, exhibition) and light processing operations (such as packaging, labeling, quality control, sorting) and re-exported. If the FEZ authority pursues the right policies the FTZ will experience growth and later on maturity and the inevitable decline. When the FTZ is operating successfully there will be two forces for change: from the host country side and from the source country. The host country may not be content with re-export business and may see an opportunity in creating more local valueadded products by attracting foreign manufacturers. On the other hand the source country may be seeking low cost labour to produce labour-intensive products. At this point the interests of the host and source countries coincide; FEZ policies and incentives are likely to change into attracting EPZ firms.

Figure 1: Life Cycle of Free Economic Zones

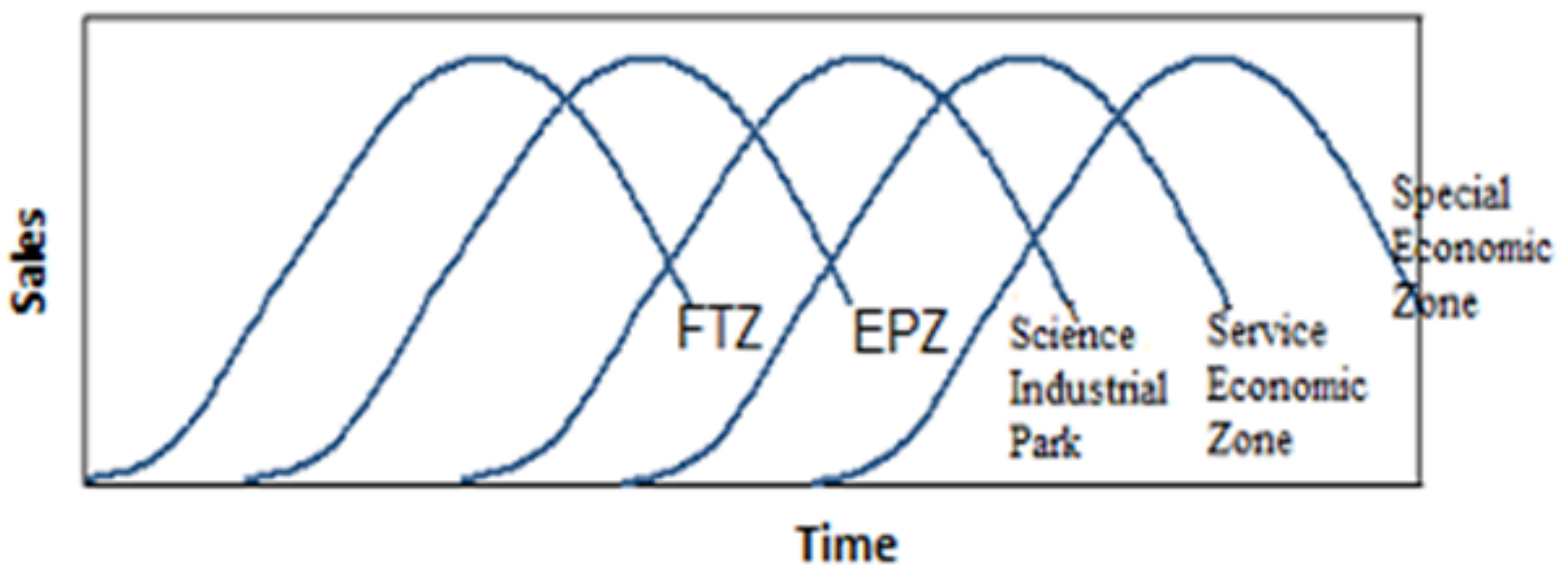

As the EPZ concept is implemented it may lead to growth; but the host country may still want to move from cheap labor-intensive production to more sophisticated technology intensive 
higher wage manufacturing. The host government is likely to take an active role in upgrading the technology capabilities of firms in the EPZs. In order to facilitate the transition, forwardthinking developing countries make substantial investment in technology and skills upgrading. The Singaporean government agency for implementing such policy was the Skills Development Fund of the Economic Development, in Malaysia it was the Penang Skills Development Centre, in Taiwan it was the Satellite Relations Program, and in Costa Rica it was the Investment Board (Omar \& Stoever, 2008).

Service Zones arise when a country feels that its growth is being restricted by focusing on trade and manufacturing. The country then decides to diversify its free economic zones concept beyond manufacturing to services such as tourism and financial services.

Special Economic Zones arise when a country sees that the concept of zones is restricting its growth in terms of functions and spatial space. This led to the more comprehensive special economic zones (SEZs). A SEZ is a large-scale FEZ that combines all types of activities trade, manufacturing, service, science and permits on-site residence. SEZs can include entire economic regions, the populations that live and work in these regions, and all the economic activities that take place there. One can speculate that the SEZ concept will also reach maturity and at that point one may need to liberalise the whole country or regions to maximise benefits to the country.

Do all FEZs necessarily evolve through the five phases suggested here? There is no one fixed way or format on how the evolution of FEZ should follow. This will to some extent be determined by the specific characteristics of a country such as locational advantages and level of economic development. The sequential approach used in this paper may help a policy maker develop his/her own sequence. Regardless of the specific conditions of a country, it is, however, important that an FEZ planner operate to a theory. This theoretical approach to FEZ evolution is based on the practical experience of other countries and some theory. If used effectively it can be a rapid method to familiarize a policy maker with the analysis of a variety of FEZ situations, predict the next phase and facilitate design of appropriate policies that promote sustainable FEZ development.

\section{Conclusions}

\section{CONCLUSIONS, LESSONS AND FUTURE RESEARCH}

This study investigated the evolution of FEZs using the functional criteria. The methodology of study involved analysis of the literature. Three main conclusions were revealed by the study about FEZ evolutions:

1. First, the functional typology shown in Table 1 should be treated with caution for it does not include all the variants of FEZs.

2. Second, and most important, the analysis suggests that as FEZs evolve functionally, they engage in more comprehensive activities (trade, manufacturing) and more sectors (services, science, residential issues) with a stronger orientation toward technology and skill intensive manufacturing and services.

3. Third, not all zones necessarily go through all the five stages of FEZ evolution and in the same order. This will to some extent be determined by the stage of economic development of a country and preferences of policy-makers. Regardless of the situation at hand, it is, however, important that FEZ policy-makers appreciate theory. The point is that good FEZ policies involve the joint use of a generally accepted theory as well as judgment skills.

4. Fourth, FEZs are attractive to investors because of the existence of policy failures in the greater host economy: as policy reforms happen investors will see no need for staying 
in the FEZs and the relative significance of FEZs in economic terms can be expected to decline; at this point FEZ and non-FEZ firms would be treated equally.

\section{Tentative Guidelines or Lessons}

The key findings presented in this paper provide lessons useful to policymakers and practitioners in planning and evaluating zone initiatives. The end result of this paper is a general guideline for zone development, which is intended to optimize results for both host countries and investing firms.

\section{Lesson 1: Start with Trade-Intensive Activities}

Historically, the typical FEZs started with entrepot trading activities. There is less risk with this approach for it involves less investment in infrastructure by the host country. As experience in marketing the imported products increases the host country can start manufacturing or assembly of the imported products for export to other markets including to the host country.

\section{Lesson 2: Proceed into Labor-Intensive Manufacturing}

It seems that the second step in the development of an FEZ, in a developing country, is normally attracting labor-intensive manufacturing activities that complement and support comparative advantage of the country in question. This step can uplift the skills of the local people, provided that regulatory guidance is used to channel capital inflows to the appropriate sectors. For example, in 1982, in Shenzhen, the SEZ authorities issued strong guidelines to foreign investors on which sectors FDI should focus (FEZ (Farole \& Akinci, 2011:198). Small manufacturing (mainly processing and assembly) enterprises in mature industries were set up, based on cheap labour. Mature industries are encouraged because they use an already established technology and hence can be manufactured by lower skilled labour. In this situation, the less developed countries may be able to undersell the more advanced countries by applying their less-skilled cheap labour to the technology already designed to product.

If the firms in the FEZs focus on industries in which the country has comparative advantage, it increases the likelihood of the local economy capturing the spill-overs from foreign direct investment. This can happen by creating zone linkages with the local economy through integrating local raw materials and intermediate inputs. In fact one of the reasons for failure of several African zones has been identified as the tendency to become enclave economies, without development of backward and forward linkage with industries with the local economy("Centre for Education and Documentation," 2009). In fact, as long as the industries that are licensed to operate in the Zones are those in which the country has comparative advantage, a natural incentive for local firms to sell goods and services to zone-based companies develops because such sales are regarded as exports and therefore eligible for export incentives.

\section{Lesson 3: Upgrade into Technology-Intensive Manufacturing}

The third step in developing FEZs is gradually transitioning from low-end cheap labourintensive manufacturing to higher-end technology-intensive manufacturing. This process should be gradual in view of the fact that technological competences take time to build up. In the case of Shenzhen, the transition to high-end technology-intensive manufacturing was brought on naturally and by regulation. Two natural factors were in operation - the cost of land went up making it no longer a place for labour-intensive manufacturing industries and the need to differentiate because of increasing competition from other FEZs. Through regulations the government deliberately enacted strong laws protecting intellectual property rights. In the case of Taiwan, the transition to high-end technology-intensive manufacturing was done mainly through government regulation: new garment industries were not allowed in Taiwan's 
EPZs as of 1974 (Farole \& Akinci, 2011:200).

\section{Lesson 4: FEZs are a Transitory Policy Instrument}

FEZs are attractive to investors because of the existence of policy failures in the host country. As liberalization continues, investors will see no need for staying in the FEZs and the relative significance of FEZs in economic terms can be expected to decline. Thus, a country's export-led growth strategies cannot rely solely on FEZs to achieve higher levels of economic growth in the long-term. A country should acknowledge the transitional nature of FEZs, and manage wisely the opportunities they may bring to upgrade labour and managerial skills, acquire superior technology and access foreign markets. In other words, FEZ should be a part of a more extensive package of policies aimed at improving the international competitiveness (Jenkins, Esquivel, \& Felipe, 1998). Successfully incorporating FEZs into the national economy requires periodic revisions of the FEZ regulations to accommodate changing national economic conditions. As the goals and roles of FEZs shift, many of the incentives will have to change. For best results there is need to change FEZ regulatory policies to support their natural and desired evolution into the next stage.

A good example of transition is the EPZs in Taiwan that have become less necessary in recent years as the total economy is almost completely reformed. In China, FEZs are still necessary because the Chinese economy is not completely reformed. This implies that establishing an export processing zone in an economy that has already reformed its macroeconomic policies is not recommended on the ground that low FDI flows may be due to inadequate legal or regulatory framework on important areas such as property ownership or labour laws. After all FEZs are not the first best policy option for development for they distort economic development and re-introduces an element of discretion into the policy environment. This implies that FEZ policy and domestic reforms should be formulated so that eventually the same treatment applies to all firms.

\section{SUGGESTIONS FOR FUTURE RESEARCH}

The functional criterion for classification employed in this study provides a natural guide to future research. This study focused on the type of industry or activity to classify FEZs. This begs the question "what other criteria or dimensions" could be used to classify FEZs? During the course of this research, two other criteria for classifying FEZs were implied as discussed below.

1. Future researchers may consider studying and classifying FEZs on the basis of their spatial location. FEZs are found in various locations including: coastal versus inland, urban versus rural, intra-national versus cross-border regions. One may investigate FEZ locations with a view to discover common location patterns and common characteristics of the locations such as a high degree of accessibility.

2. This study was literature based. It involved extensive literature review on several experiences of FEZs from various countries. Future researchers could conduct an empirical survey study on many FEZs on a topic such as "identification and ranking factors influencing the evolution of free trade zones".

3. Another similar study could follow the case method approach by carrying out an intensive study of a relatively small number of FEZs or a single FEZ. The case(s) should be helpful in providing detailed and in-depth understanding on the factors that influence the evolution of a FEZ. Case studies which demonstrate the way in which successful FEZs evolved over time may be a useful starting point. 


\section{References}

Chen, X., and de'Medici, T. (2009). The "Instant City" Coming of Age: China's Shenzhen Special Economic Zone in Thirty Years. Center for Urban and Global Studies at Trinity College Working Paper No. 2.

Chen, X. (1994). The changing roles of free economic zones in development: a comparative analysis of capitalist and socialist cases in East Asia. Studies in Comparative International Development.

Farole, T. 2011. Special Economic Zones in Africa: Comparing Performance and Learning from Global Experience. The World Bank, Washington DC.

Farole, T. \& Akinci, G. (2011). Special Economic Zones: Progress, Emerging Challenges, and Future Directions. World Bank. https://openknowledge.worldbank.org/handle/10986/2341 License: CC BY 3.0 IGO.

FIAS (2008). Special Economic Zones: Performance, Lessons Learned, and Implications for Zone Development. The Multi-Donor Investment Climate Advisory Service of the World Bank Group. Washington, DC.

Ge, W. (1999). Special Economic Zones and the Opening of the Chinese Economy: Some Lessons for Economic Liberalization. World Development, 27(7), 1267-1285 doi.org/10.1016/S0305-750X(99)00056-X

Jayanthakumaran, K. (2003). Benefit-Cost Appraisals of Export Processing Zones: A Survey of the Literature. Development Policy Review, 21(1): 51-65. DOI: 10.1111/1467-7679.00198.

Jenkins, M., Esquivel, G. \& Felipe, L.B. (1998). Export Processing Zones in Central America Discussion Paper No. 646.

Madani, D. (1999). A Review of the Role and Impact of Export Processing Zones. World Bank Policy Research Paper No. 2238, The World Bank. Washington DC.

Meng, G. (2005). Evolutionary Model of Free Economic Zones. Chinese Geographical Science, 15(2): 103-112. https://doi.org/10.1007/s11769-005-

Omar, K. \& Stoever, W.A. (2008). The role of technology and human capital in the EPZ life-cycle, 17(1): 135-159.

Pakdeenurit P., Suthikarnnarunai, N., and Rattanawong, W. (2014). Proceedings of the International MultiConference of Engineers and Computer Scientists, 2014 Vol II, IMECS 2014, March 12 - 14, 2014, Hong Kong

Rondinelli, D.A. (1987). Export Processing Zones and Economic Development in Asia: A Review and Reassessment of a Means of Promoting Growth and Jobs. American Journal of Economics and Sociology, 46(1). DOI: $10.1111 / \mathrm{j} .1536-7150.1987 . t b 01766 . x$

Suazer-villa, L. (1985). Urban growth and manufacturing change in the United States-Mexico borderlands: A conceptual framework and an empirical analysis. The Annals of Regional Science, 19 (3): 54-108. /doi.org/10.1007/BF01294831

Warr, P.G. (1987). Malaysia's industrial enclaves: Benefits and costs. The Developing Economies, 25(1), 30-55. DOI: $10.1111 /$ j.1746-1049.1987.tb00098.x

Wong, K.Y. and D.K.Y. Chu (1984). Export processing zones and special economic zones as generators of economic development: the Asian experience. Geografisca Annaler 66B(1): 1-16. DOI: 10.2307/490524

World Bank (2008). Global Economic Prospects 2008.

Zhan, Q. (1993). The special economic zones of various countries in the world. Special Zone and Open City Economy, 2, 62-74. 